\title{
Identification and Differentiation of Tilletia indica and T. walkeri Using the Polymerase Chain Reaction
}

\author{
Reid D. Frederick, Karen E. Snyder, Paul W. Tooley, Yvette Berthier-Schaad, \\ Gary L. Peterson, Morris R. Bonde, Norman W. Schaad, and David A. Knorr
}

First through seventh authors: United States Department of Agriculture-Agricultural Research Service, Foreign Disease-Weed Science Research Unit, 1301 Ditto Avenue, Fort Detrick, MD 21702; and eighth author: Perkin-Elmer/Applied Biosystems, 850 Lincoln Centre Drive, Foster City, CA 94404.

Current address of D. A. Knorr: Lynx Therapeutics, 25861 Industrial Blvd., Hayward, CA 94545.

Current address of K. E. Snyder: Dept. of Plant Pathology, University of Georgia, Athens, GA 30602.

Accepted for publication 22 May 2000.

\begin{abstract}
Frederick, R. D., Snyder, K. E., Tooley, P. W., Berthier-Schaad, Y., Peterson, G. L., Bonde, M. R., Schaad. N. W., and Knorr, D. A. 2000. Identification and differentiation of Tilletia indica and T. walkeri using the polymerase chain reaction. Phytopathology 90:951-960.

Karnal bunt of wheat, caused by Tilletia indica, was found in regions of the southwestern United States in 1996. Yield losses due to Karnal bunt are slight, and the greatest threat of Karnal bunt to the U.S. wheat industry is the loss of its export market. Many countries either prohibit or restrict wheat imports from countries with Karnal bunt. In 1997, teliospores morphologically resembling $T$. indica were isolated from bunted ryegrass seeds and wheat seed washes. Previously developed PCR assays failed to

differentiate $T$. indica from the recently discovered ryegrass pathogen, $T$. walkeri. The nucleotide sequence of a $2.3 \mathrm{~kb}$ region of mitochondrial DNA, previously amplified by PCR only from $T$. indica, was determined for three isolates of $T$. indica and three isolates of $T$. walkeri. There was greater than $99 \%$ identity within either the $T$. indica group or the $T$. walkeri group of isolates, whereas there was $\approx 3 \%$ divergence between isolates of these two Tilletia species. Five sets of PCR primers were made specific to $T$. indica, and three sets were designed specifically for $T$. walkeri based upon nucleotide differences within the mitochondrial DNA region. In addition, a $212 \mathrm{bp}$ amplicon was developed as a target sequence in a fluorogenic $5^{\prime}$ nuclease PCR assay using the TaqMan system for the detection and discrimination of $T$. indica and $T$. walkeri.
\end{abstract}

Tilletia indica Mitra infects wheat, durum wheat, and triticale and causes a disease commonly referred to as Karnal bunt. The disease was first described in the village of Karnal, India in 1930 (16). Since then Karnal bunt has been found in the neighboring countries of Pakistan, Nepal, Iraq, and Afghanistan (4). Karnal bunt was reported first on the North American continent in 1972 when it was found in Mexico (10), and by 1982 the disease had become well established in wheat fields in northwestern Mexico (5). Subsequently, in March of 1996, Karnal bunt was discovered in wheat in the United States in Arizona and later that year in California $(5,26)$. In 1997, the disease was discovered in a small area of central Texas (5).

Yield reductions in wheat from Karnal bunt are slight; however, the disease is of extreme economic importance. Many countries, including the U.S., have a zero tolerance for Karnal bunt and refuse wheat shipments from quarantined countries and/or areas

Corresponding author: R. D. Frederick; E-mail address: frederir@ncifcrf.gov

The United States Department of Agriculture (USDA) prohibits discrimination in its programs on the basis of race, color, national origin, sex, religion, age, disability, political beliefs, and marital or familial status. Persons with disabilities who require alternative means for communication of program information (Braille, large print, audiotape, etc.) should contact the USDA Office of Communications at (202) 720-5881 (voice) or (202) 720-7808 (TDD). To file a complaint, write the Secretary of Agriculture, United States Department of Agriculture, Washington, DC 20250, or call (202) 720-7327 (voice) or (202) 7201127 (TDD). The USDA is an equal employment opportunity employer.

Publication no. P-2000-0711-03R

This article is in the public domain and not copyrightable. It may be freely reprinted with customary crediting of the source. The American Phytopathological Society, 2000
(18). Since the U.S. is the world's leading exporter of wheat with an estimated annual value of $\$ 5$ billion, Karnal bunt poses a serious threat to international trade for the U.S. wheat industry $(7,18)$.

Prior to the discovery of Karnal bunt in the U.S., polymerase chain reaction (PCR) primers were developed at our research facility to distinguish $T$. indica from other smut fungi $(11,23)$. $T$. barclayana, which causes rice kernel smut, sometimes is present as a contaminant in harvested or stored wheat and can be misidentified as $T$. indica. These primers were used to confirm the identity of the pathogen as $T$. indica following discovery of teliospores in the southwestern U.S.

During the 1996 National Karnal Bunt Survey conducted by the Animal and Plant Health Inspection Service (APHIS) of the United States Department of Agriculture (USDA), teliospores morphologically similar to $T$. indica were discovered as free spores in seed washes of wheat from the southeastern United States and in forage-mix seed lots from Oregon, but no infected wheat seeds were found $(5,8,18)$. Further investigation revealed that the teliospores originated from bunted annual ryegrass (Lolium multflorum) seeds present as contaminants in wheat from fields in these areas. The existing PCR primers did not distinguish this newly discovered ryegrass smut pathogen from $T$. indica. The ryegrass smut was described recently as $T$. walkeri Castlebury and Carris on the basis of teliospore morphology and ornamentation (7). Distinguishing $T$. indica from $T$. walkeri requires examination of many teliospores by trained mycologists. This process is inefficient, tedious, and subject to misinterpretation.

In this study, nucleotide sequences of a 2.30-kilobase region of mitochondrial DNA (mtDNA), previously amplified by PCR only from $T$. indica (11), were determined for three isolates each of $T$. indica and T. walkeri. Based upon nucleotide differences, we report 
here the development of improved classical PCR assays and a new TaqMan test for the detection and discrimination of $T$. indica from T. walkeri and other related smut species. Preliminary reports of this research have been made $(12,13)$.

\section{MATERIALS AND METHODS}

Fungal isolates and growth conditions. A list of the Tilletia isolates used in this study is shown in Table 1. The isolates were from bunted seed samples or seed washes. Mycelial cultures were grown on potato dextrose agar (PDA) plates at $21^{\circ} \mathrm{C}$ for 7 to 10 days. Secondary sporidia were produced by placing mycelial plugs onto $2 \%$ water-agar plates and incubating them at $21^{\circ} \mathrm{C}$ for 3 to 4 days. Mycelial tissue used for extracting genomic DNA was grown and prepared as follows: Mycelial plugs (each $3 \mathrm{~cm}^{2}$ ) cut from water-agar plates were placed inverted on the inside surface cover of a $100 \times 15 \mathrm{~mm}$ petri plate containing sterile potato dextrose broth. After approximately 10 days of incubation at $21^{\circ} \mathrm{C}$, mycelia and spores floating on the broth were harvested by filtration through a Buchner funnel onto Whatman filter paper, and the tissue was blotted dry and stored at $-80^{\circ} \mathrm{C}$.

DNA extraction and recombinant DNA techniques. Genomic DNA from $T$. indica and T. walkeri was extracted from 0.5 to $1.0 \mathrm{~g}$ frozen mycelial tissue. The tissue was placed into $1.5-\mathrm{ml}$ microcentrifuge tubes with $75 \mu$ lysis buffer and ground with a sterile pestle attached to a power drill. An additional $75 \mu \mathrm{l}$ of lysis buffer was added, and DNA was extracted using a Puregene Genomic DNA Isolation kit (Gentra Systems, Minneapolis, MN) according to the manufacturer's directions. DNA concentrations were determined by UV spectrophotometry at $260 \mathrm{~nm}$.

A 2.3-kb fragment was amplified from three $T$. indica isolates (Yv3b, WL1562, and Bpop) and three T. walkeri isolates (210G, YRG-001, and TNRG-02) by PCR using the oligonucleotide primers Ti-1 and Ti-4 (synthesized by Life Technologies/Gibco BRL, Gaithersburg, MD) as described previously (11). The fragments from these isolates were cloned into the TA cloning vector pCR2.1 (Invitrogen Corp., Carlsbad, CA) and transformed into $E$. coli $\mathrm{INV} \propto \mathrm{F}^{\prime}$ cells according to the manufacturer's directions.

DNA sequencing and analysis. Plasmid DNA containing the 2.3-kb mtDNA fragment from $T$. indica or $T$. walkeri isolates was extracted from $E$. coli using a Qiagen Plasmid DNA kit following the manufacturer's procedure (Qiagen, Inc., Chatsworth, CA). DNA concentrations were determined by UV spectrophotometry at $260 \mathrm{~nm}$, and nucleotide sequence was determined (Sequetech Corp., Mountain View, CA). Nucleotide sequences were compared and aligned in our laboratory using the Bestfit and Pileup programs of the Genetics Computer Group computer package (version 9.0) (9) at the Advanced Biomedical Computing Center of the National Cancer Institute, Frederick, MD.

PCR assay and Southern blot analysis. Oligonucleotide primers specific to either T. indica or $T$. walkeri were synthesized to unique sequences within the 2.3-kb mtDNA regions (Life Technologies/Gibco BRL). Classical PCR reactions were performed in a Gene AMP PCR System 9700 thermocycler (Perkin-Elmer/ Applied Biosystems, Inc., Foster City, CA) using 25 ng of genomic DNA. PCR was performed in a total volume of $25 \mu \mathrm{l}$ containing: $10 \mathrm{mM}$ Tris-HCl; $50 \mathrm{mM} \mathrm{KCl}\left(\mathrm{pH} \mathrm{8.3);} 1.5 \mathrm{mM} \mathrm{MgCl}_{2}\right.$; $0.001 \%$ (wt/vol) gelatin; dATP, dGTP, dCTP, and dTTP, each at a concentration of $100 \mathrm{mM}$; each primer at a concentration of $100 \mathrm{nM}$; and $0.5 \mathrm{U}$ of AmpliTaq DNA polymerase (Perkin-Elmer/Applied Biosystems). The $T$. indica-specific PCR primers Tin3 (5'-CAATGTTGGCGTGGCGGCGC-3')/Tin10 (5'-AGCTCCGCCTCAAGTTCCTC-3'), F3 (5'-GGCACCAGAGTACAGCTGTCGTT3')/R1 (5'-GTCGGATTTGCGGACACTTTC-3'), Tin3/Tin6 (5'-GGCGGACTACCACTCGAGCT-3'), Tin5 (5'-GACGTCGAGGCCGACCGTAT-3')/Tin6, and Tin3/Tin4 (5'-CAACTCCAGTGATGGCTCCG-3') were used with the following cycling conditions: $94^{\circ} \mathrm{C}$ denaturation for $1 \mathrm{~min}, 25$ cycles of $94^{\circ} \mathrm{C}$ for
$15 \mathrm{~s}, 65^{\circ} \mathrm{C}$ for $15 \mathrm{~s}$, and $72^{\circ} \mathrm{C}$ for $15 \mathrm{~s}$, followed by an extension step of $72^{\circ} \mathrm{C}$ for $6 \mathrm{~min}$.

The $T$. walkeri-specific PCR primers Tin11 (5'-TAATGTTGGCGTGGCGGCAT-3')/Tin4 were used at the same conditions as described for the $T$. indica-specific PCR primers, however for the $T$. walkeri primers Tin7 (5'GTTTGAGCCACGCTATGACC3')/Tin8 (5'-GGCTCATCTACGCATACGTT-3') the number of cycles was increased to 30 . For the $T$. walkeri primers Tin11/ Tin10 (5'-AGCTCCGCCTCAAGTTCCTC-3'), an annealing temperature of $55^{\circ} \mathrm{C}$ was employed for 45 cycles.

Negative controls were tested by using the same reaction mixture under the amplification conditions described above without template DNA. To verify that DNA extracted from $T$. indica and $T$. walkeri isolates could be amplified by PCR, primers ITS2 and ITS5 (25) were used to amplify an internal transcribed spacer region of the rDNA. DNA fragments produced by PCR were analyzed by electrophoresis on $1.4 \%$ agarose gels in $0.5 \mathrm{X}$ TBE buffer stained with ethidium bromide (2).

Gels for Southern blots were denatured and blotted onto positively charged nylon membranes (Boehringer-Mannheim, Indianapolis) (2), and the blots were hybridized for 14 to $16 \mathrm{~h}$ at $55^{\circ} \mathrm{C}$ with the 2.3-kb mtDNA region from $T$. indica isolate WL1562 that was labeled with digoxigenin according to the manufacturer's directions (Boehringer-Mannheim). Chemiluminescent detection was performed as directed by the manufacturer (BoehringerMannheim), and the membranes were exposed to X-ray film (Blue sensitive; Molecular Technologies, St. Louis) at room temperature for up to $20 \mathrm{~min}$.

TaqMan 5' nuclease PCR assay. The PCR conditions were a modification of the classical PCR assays described above for the $T$. indica-specific primers Tin3/Tin 10 and the $T$. walkeri-specific primers Tin11/Tin10. Cycling conditions consisted of the following: $50^{\circ} \mathrm{C}$ for $2 \mathrm{~min}, 95^{\circ} \mathrm{C}$ for $10 \mathrm{~min}$, and 34 cycles of $95^{\circ} \mathrm{C}$ for $15 \mathrm{~s}$ and $60^{\circ} \mathrm{C}$ for $1 \mathrm{~min}$. The $5^{\prime}$ nuclease assays were performed using an ABI Prism 7700 Sequence Detection System (PerkinElmer/Applied Biosystems) in a total volume of $25 \mu$ containing 1X TaqMan Universal Master Mix (Perkin-Elmer/Applied Biosystems), $400 \mathrm{nM}$ of either Tin3/Tin10 or Tin11/Tin10, and $12.5 \mathrm{ng}$ of genomic DNA. The TaqMan probe, $5^{\prime}$-ATTCCCGGCTTCGGCGTCACT-3', was labeled at the $5^{\prime}$-end with the fluorescent reporter dye, 6-carboxy-fluorescin (FAM) and at the $3^{\prime}$ end with the quencher dye, 6-carboxy-tetramethyl-rhodamine (TAMRA) (Perkin-Elmer/Applied Biosystems). The probe was used at $400 \mathrm{nM}$ in both the $T$. indica-specific and the $T$. walkeri-specific assays. Dilution series of genomic DNA extracted from $T$. indica isolate Bpop and T. walkeri isolate YRG-001 were prepared in sterile distilled water.

Nucleotide sequence accession numbers. The 2,300 bp mtDNA sequence of $T$. indica isolates Yv3b, WL1562, and Bpop and $T$. walkeri isolates 210G, TNRG-02, and YRG-001 have been deposited at GenBank and have been assigned the accession numbers AF218058, AF218059, AF218060, AF218061, AF218062, and 218063 , respectively.

\section{RESULTS}

Sequence comparison of a 2.3-kb region of mtDNA from $\boldsymbol{T}$. indica and $\boldsymbol{T}$. walkeri. A 2.3-kb region of mtDNA was amplified by PCR using the primers Ti-1 and Ti-4 from three isolates each of T. indica and T. walkeri, and the PCR products were cloned. The nucleotide sequence was determined for each isolate, and comparisons were made among the isolates from the same species and between the two Tilletia species. Among the three $T$. indica isolates, only two differences were found among the 2,297 nucleotides ( $>99.9 \%$ similarity). Likewise, when the three $T$. walkeri sequences were analyzed, 13 differences were observed among the 2,300 nucleotides (99.4\% similarity). The comparison of $T$. indica and T. walkeri sequences revealed 69 nucleotide differences (Fig. 1), 
most of which were randomly scattered throughout the $2.3-\mathrm{kb}$ region. In each case, however, three nucleotides (CAG) were absent from the $T$. indica sequences corresponding to nucleotide positions 214 through 216 in T. walkeri. BLAST searches of nucleic acid and protein databases with the $T$. indica and $T$. walkeri 2.3 -kb mtDNA sequences did not reveal any significant matches in either database (1).

Selection of species-specific primers and the development of PCR assays. Although the overall sequence similarity is high

\begin{tabular}{|c|c|c|}
\hline Ti & TGGGCTGAGTCTGAGATGCAGAGCCTGCACTCCCGAAAACGTCGACGAGTTTYKGCCGAACGAAGCGTGTGCGACACCCGA & 80 \\
\hline Tw & FGGGCTGAGTCTGAGATGCAGAGCCTGCACTCCCGAAAACGTCGACGAGTTTHGCCGAACGAAGCGTGTGCGACACCCGA & 80 \\
\hline Ti & ATCCGTGGAAGAACAACGCTGAGTGATCCTAGCTGAGCTAACGCCGTCCTGGATTGTGCACTCTTCGTCACCGCCGTTGC & 160 \\
\hline$T w$ & ATCCGTGGAAGAACAACGCTGAGTGATCCTAGCTGAGCTAACGCCGTCCTGGATTGTGCACTCTTCGTCACCGCCGTTGC & 160 \\
\hline $\mathrm{Ti}$ & GCGCTTAGCGTGAATGCTCCTGGAAGCCACAGACTATCAGCAAATGACTCGAA & 237 \\
\hline$T w$ & GCGCTTAGCGTGAATGCTCCTGGAAGCCACAGACTATCAGCAAATGACTCGAAO\% & 240 \\
\hline$T i$ & CTCACTTGAGCGGCTCGCCTTCTTCTTCTGCAATAGTACCTGTGGGCTCWCC:AGGGAAGGACTGCCAGGCTCTCCTTGG & 317 \\
\hline$T_{W}$ & CTCACTTGAGCGGCTCGCCTTCTTCTTCTGCAATAGTACCTGTGGGCTCWCCAGGGAAGGACTGCCAGGCTCTCCTTGG & 320 \\
\hline Ti & CH & 397 \\
\hline$T^{w}$ & CTSGCACCAGAGTACAGCTTCGTECTTCCTGCCTCGTTTTCACCAGAGACATGACTTTCATGATGGCCTCMATACCOAC & 400 \\
\hline$T i$ & GTTGGTCTCGGCCAGTTCCACGCCWACATGGACCGCTTCGCGTTGCCTGATCTGCATCGACGGTCCCAAIACGAAGTTGA & 477 \\
\hline Tw & GTTGGTCTCGGCCAGTTCCACGCCAACATGGACCGCTTCGCGTTGCCTGATCTGCATCGACGGTCCCAATACGAAGTTGA & 480 \\
\hline$T i$ & TTTCCTCAA俞GTCCTGCTAGCCGAG & 557 \\
\hline Tw & CCCGAAAGGCGCTGAGCCCTGGCAGGGACATGAGCCGTGCCGAGTCAGGAATCGTTTTCCTCAAGGTCCTGCTAGCCGAG & 560 \\
\hline$T i$ & SCAGAXGTTGCCCAACCAGAATCAGAAGAGAATGTGGAGTCGGCAATAGGCTCGAG & 637 \\
\hline$T W$ & CCGGCHTCGCCGTAATAGCCCTGTGCAGA僧CTTGCCCAACCAGAATCAGAAGAGAATGTGGAGTCGGCAATAGGCTCGAG & 640 \\
\hline$T i$ & ITGTTTAGCTIGCTCGTGCTGCTTGACC & 717 \\
\hline$T w$ & CGCCCAATCCGCCCACCGATCCGTGAATCCGCTCAAAGTGAGCGTGTTCATGGTGTTTAGCTTACTCGTGCTGCTTGACC & 720 \\
\hline$T i$ & 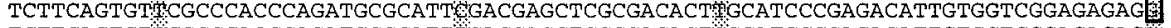 & 797 \\
\hline$T w$ & $\begin{array}{l}\text { TCTTCAGTGT } 1 \text { CGCCCACCCAGATGCGCATTTGACGAGCTCGCGACACTEGCATCCCGAGACATTGTGGTCGGAGAGAGA } \\
\text { Ri }\end{array}$ & 800 \\
\hline Ti & 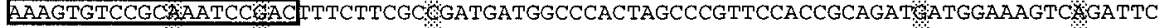 & 877 \\
\hline Tw & AAAGTGTCCGCGAATCCAACTTTCTTCGCHGATGATGGCCCACTAGCCCGTTCCACCGCAGATAATGAAAGTCGGATTC & 880 \\
\hline$T i$ & AGCCCGAACGATCCGTCTGACCGGGGACATGCTTTGAACAAATGTTGGCG? & 957 \\
\hline$T w$ & 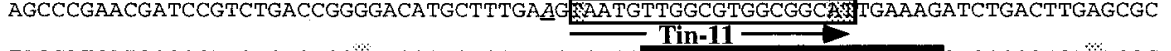 & 960 \\
\hline$T i$ & TAGGATCATGCGGCAAGTCTGAGGMATCGCTGTCCATAGACTGOAGTGACGCCGAAGCCGGGAAT GAGCCGGTCA & 1037 \\
\hline Tw & $\begin{array}{l}\text { TAGGATCATGCGGCAAGTCTGAGGQATCGCTGTCCATAGACTGOAGTGACGCCGAAGCCGGGAATGAGCCGGTCARAGGC } \\
\mathbf{P}\end{array}$ & 1040 \\
\hline Ti & GGAGAGGC:OAGAAGCTCGGCCA GAGGAACTTGAGGCGGAGCTCTGCTGTTTTTCGCO TCGAACCACCGAGCCGTGGTGGT & 1117 \\
\hline TW & 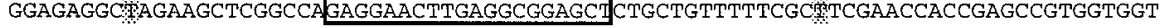 & 1120 \\
\hline$T i$ & CTGGTATGGAGAATAVATACTACC菏TCGGCAGAACC & 1197 \\
\hline TW & CTGGTATGGAGAATAXATACTACCOTCGGCAGAACC & 1200 \\
\hline Ti & CAGCATCGCTCGAGCCACTCCGTTGGTGGCCACGCGA & 1277 \\
\hline TW & CAGCATCGCTCGAGCCACTCCGTTGGTGGCCACGCGATCGGTGGCGA.CCGGTGCCGAAAATAGGGGTTGCTTCGCCGCT & 1280 \\
\hline$T i$ & TCGTGAGTGCCATACTCTTCATËGCCCTCACTATCGGAGCCATCACTGGAGTTGRCATGGTTGACACGAG KATCKTCGC & 1357 \\
\hline TW & TCGTGAGTGCCATACTCTTCATEGCCCTCACTATCGGAGCCATCACTGGAGTTGTCATGGTTGACACGAGGTCGGTCGC & 1360 \\
\hline$T i$ & CT GACGTCGAGGCCGACCGTAMCGGTCTTGTCCTCTTACCGGTCTCAAAGGTGAC & 1437 \\
\hline TW & CTGACGTCGAGGCCGACCATA\&CGGTCTTGTCCTCTTACCGGTCTCAAAGGTGACCTTGCTGGGGACTGCGTGTTTTCAT & 1440 \\
\hline Ti & GGCCGTCCCTCGAAGAATGGAGGCCGGGMGAAGGTA & 1517 \\
\hline TW & GGCCGTCCCTCGAAGAATGGAGGCCGGG\%GAAGGTATTTGGAAGAAGCTGTCCCTCTTGTTTGCACTGCGTGAAGGTTGC & 1520 \\
\hline Ti & CGAAAXGGTGCGGTTCGGAAAAGGGGTCCGGTTCG & 1597 \\
\hline TW & CGHAATGCGTGCGGTTCGGAAAAGGGGTCCGGTTCGCCTGTCACGAAAAGCGCTTCGAAGACCTGAATTGACTCAAAAGT & 1600 \\
\hline$T i$ & CAGCTT\&AAGCTTCCATTCGCGGCGGGGACGCCAGCO & 1677 \\
\hline TW & CAGCTI IAAGCTTCCATTCGCGGCGGGGACGCCAGCCATTACGAAGGCGGTGGCACCTCTCGCCCCAGAACCGATTCGAT & 1680 \\
\hline$T i$ & TTGGCATTGCAGCGAGCATTTCAGTSATGCTATTTTGAACGCCTGGTATTCTCGA䜿GCTCGAGTGGTAGTCCGCOCGTGA & 1757 \\
\hline Tw & TTGGCATTGCAGCGAGCATTTCAGTKATGCTATTTTGAACGCCTGGTATTCTCGA\&GCTCGAGTGGTAGTCCGCCCGTGA & 1760 \\
\hline Ti & AGQGTSTGAGCCA TGCTATGACPATTC & 1837 \\
\hline Tw & AGPGIRTGAGCCAEGCTATGACSATTCGCTGCGGTTCTGTTYTTGGAGGACCAGCCTTCGGACTGTATGGGCATGTCCTT & 1840 \\
\hline$T i$ & ATCGGAAGGGAGATTTTGTCCOAGTCCATY & 1917 \\
\hline$T w$ & TATAGCTGEATCGGAAGGGAGATTTTGTCCAAGTCCATTEGCTGAAGACGGCGGTGTGACCTGTGCTCGTCCACGATGCT & 1920 \\
\hline$T i$ & TGGCAGAGACGACTTTCATC & 1997 \\
\hline Tw & CTACATGTCTGGCAGAGACGACTTTCATCGAATAACGAGCTCCCA & 2000 \\
\hline Ti & ACATAGACTTCGAGCCGATGAATCTCCAC & 2077 \\
\hline$T w$ & ACATAGACTTCGAGCCGATGAATCTCCAC & 2080 \\
\hline$T i$ & GACCCTCGTCCCCCTCAAGAGCCAAGACTG\%ATGGGT & 2157 \\
\hline$T W$ & GACCCTCGTCCCCCTCAAGAGCCAAGACTGAAT FGTGGGTATGACAGCGTCGCG ACGTATGCGTAGATGAGCOATCCGA & 2160 \\
\hline Ti & CPPAGAGTGGGACGGTGCGAAACGACGAGGCGGA G̈GTTTTGGAATCAGAGCGGA_AAAGGGTCGCCTI & 2237 \\
\hline TW & 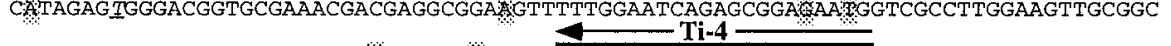 & 2240 \\
\hline$T i$ & CGCGCTGGAGGTGCACTAGCCACTGACCCGCTTCCCAG SCTATGAGACGCAGGTATTACT & 2297 \\
\hline Tw & CGCGCTGGAGGTGCACTAGCCACTGXCCCGCT\&CCCAGECTA & 2300 \\
\hline
\end{tabular}

Fig. 1. Alignment of the 2.3-kilobase mitochondrial DNA nucleotide sequences from the Tilletia indica isolate Bpop (Ti) and the T. walkeri isolate 210G (Tw) Nucleotide differences that occur among either the T. indica isolates or the T. walkeri isolates are italicized and underlined, and nucleotide differences between T. indica and T. walkeri isolates are highlighted by shaded boxes. The location of PCR primers is depicted by open boxes, and 5'-to-3' direction of each primer is shown by the arrow. The FAM-labeled TaqMan probe sequence is indicated by the black box. 
between $T$. indica and $T$. walkeri within this mtDNA region $(97.0 \%$ similarity), selective sites were identified for PCR primer development. Primer design incorporated differences at the final nucleotide position at the $3^{\prime}$-end of the oligonucleotide. Because Taq polymerase does not extend primers with 3 '-terminal mismatches (17), PCR products are produced only in those reactions where complete annealing occurs at the $3^{\prime}$-end between the DNA template and the oligonucleotide primer. Using this strategy, five sets of PCR primers were designed from regions where there is a conserved nucleotide among the three $T$. indica isolates but not among the three $T$. walkeri isolates. The five primer sets designed specifically for $T$. indica are: Tin3/Tin10, F3/R1, Tin3/Tin6, Tin5/Tin6, and Tin3/Tin4, that amplify DNA fragments of: 212, 497, 885, 392, and $414 \mathrm{bp}$, respectively (Fig. 2A).

Three sets of PCR primers were selected as T. walkeri-specific based upon characteristic nucleotides at the final nucleotide position at the 3 '-end of the oligonucleotide. The T. walkeri PCR primer sets, Tin11/Tin10, Tin7/Tin8, and Tin11/Tin4, amplified PCR products of 212, 391, and 414 bp, respectively (Fig. 2B). PCR reaction conditions were optimized for each set of PCR primers by adjusting the annealing temperature or the number of amplification cycles.
In order to verify the specificity of the $T$. indica and $T$. walkeri PCR primers, DNA was extracted from $T$. indica and $T$. walkeri isolates from different geographic areas (Table 1) and tested with each PCR primer set. The five $T$. indica PCR primer sets produced single bands using DNA from $34 T$. indica isolates, while none of the $10 \mathrm{~T}$. walkeri isolates produced a PCR product with these primers. Southern blot hybridizations confirmed the identity of the PCR product for each of the T. indica samples, and no detectable bands were observed with any of the $T$. walkeri samples (Southern blots not shown). Three T. walkeri PCR primer sets produced single bands only with DNA extracted from $T$. walkeri isolates, and no detectable DNA product was found from the $T$. indica isolates (Southern blots not shown).

TaqMan 5' nuclease assay. Fluorogenic $5^{\prime}$ nuclease assays were developed for the TaqMan system, utilizing either the $T$. indicaspecific primer set Tin3/Tin 10 or the $T$. walkeri-specific primer set Tin11/Tin10 plus an internal 5'-FAM-labeled oligonucleotide probe. In both TaqMan assays, the amplicon was $212 \mathrm{bp}$. The $\Delta \mathrm{RQ}$ values were measured at the conclusion of each amplification cycle, illustrated by the amplification plots of $T$. indica isolate Bpop and $T$. walkeri isolate YRG-001 (Fig. 3). In the T. indica-specific TaqMan assay,

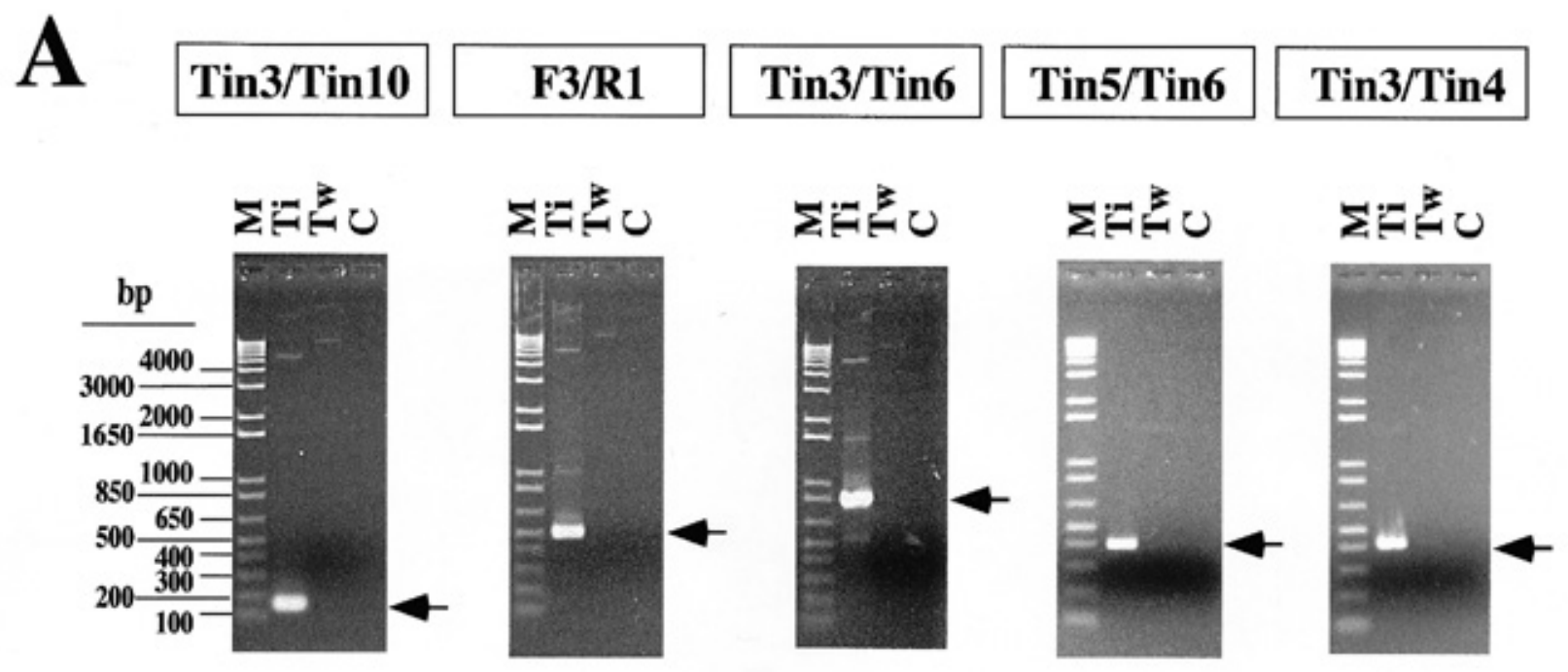

B

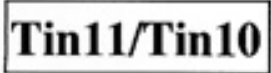

Tin7/Tin8

Tin11/Tin4
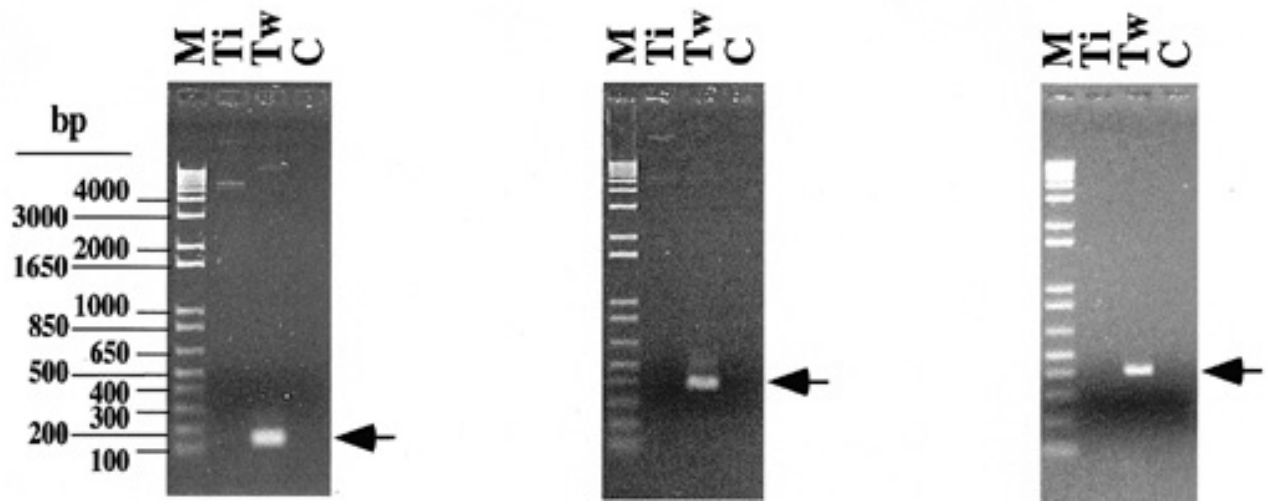

Fig. 2. Agarose gels of classical PCR assays using Tilletia indica-specific (A) or T. walkeri-specific (B) primers. $\mathrm{M}=$ molecular weight markers; $T i=T$. indica isolate Bpop; $\mathrm{Tw}=T$. walkeri isolate $\mathrm{YRG}-001$; and $\mathrm{C}=$ no DNA template control. PCR products are indicated by arrows. 
TABLE 1. Isolates of Tilletia spp. used in this study

\begin{tabular}{|c|c|c|c|c|}
\hline Isolate & Sample composition $^{\mathrm{a}}$ & Host & Origin/Year & Supplier $^{b}$ \\
\hline \multicolumn{5}{|l|}{ T. Walkeri } \\
\hline $210 G$ & SW & & Oregon, 1997 & 1 \\
\hline BPPC-0410 & $\mathrm{C}$ & Ryegrass & Oregon, 1997 & 2 \\
\hline BPPC-0518 & $\mathrm{T}$ & Ryegrass & Georgia, 1997 & 1 \\
\hline BPPC-0519 & $\mathrm{T}$ & Ryegrass & Georgia, 1997 & 1 \\
\hline YRG-001 & $\mathrm{T}$ & Ryegrass & Oregon, 1997 & 3 \\
\hline YRG-002 & $\mathrm{T}$ & Ryegrass & Oregon, 1997 & 3 \\
\hline YRG-009 & $\mathrm{T}$ & Ryegrass & Oregon, 1997 & 3 \\
\hline TNRG-02 & $\mathrm{T}$ & Ryegrass & Tennessee, 1997 & 3 \\
\hline TNRG-03 & $\mathrm{T}$ & Ryegrass & Tennessee, 1997 & 3 \\
\hline TNRG-10 & $\mathrm{T}$ & Ryegrass & Tennessee, 1997 & 3 \\
\hline \multicolumn{5}{|l|}{ T. indica } \\
\hline Bpop & $\mathrm{C}$ & Wheat & Pakistan, 1985 & 4 \\
\hline B4 & $\mathrm{T}$ & Wheat & Pakistan, 1985 & 4 \\
\hline B4-S3 & $\mathrm{B}$ & Wheat & Pakistan, 1985 & 4 \\
\hline B4-S5 & $\mathrm{B}$ & Wheat & Pakistan, 1985 & 4 \\
\hline A3 & $\mathrm{T}$ & Wheat & India, 1991 & 5 \\
\hline $\mathrm{A} 1-\mathrm{S} 3$ & $\mathrm{~B}$ & Wheat & India, 1991 & 5 \\
\hline A1-S4 & B & Wheat & India, 1991 & 5 \\
\hline A1-S5 & B & Wheat & India, 1991 & 5 \\
\hline $\mathrm{A} 4-\mathrm{S} 4$ & B & Wheat & India, 1991 & 5 \\
\hline Pantanagar 1991 & $\mathrm{C}$ & Wheat & India, 1991 & 5 \\
\hline Sangar & $\mathrm{C}$ & Wheat & India, 1991 & 6 \\
\hline WL1562 & $\mathrm{C}$ & Wheat & India, 1983 & 6 \\
\hline Sample IIB & $\mathrm{T}$ & Wheat & India, 1989 & 6 \\
\hline HD2288 A & $\mathrm{T}$ & Wheat & India, 1989 & 6 \\
\hline WL711 & $\mathrm{T}$ & Wheat & India, 1989 & 6 \\
\hline WL2265 A & $\mathrm{T}$ & Wheat & India, 1989 & 6 \\
\hline $\mathrm{Mx}-81 \mathrm{~A}$ & $\mathrm{~T}$ & Wheat & Mexico, 1981 & 7 \\
\hline D3 1981 Sonora & $\mathrm{T}$ & Wheat & Mexico, 1981 & 7 \\
\hline D3-S1 & B & Wheat & Mexico, 1981 & 7 \\
\hline D3-S2 & B & Wheat & Mexico, 1981 & 7 \\
\hline D3-S3 & B & Wheat & Mexico, 1981 & 7 \\
\hline D3-S4 & B & Wheat & Mexico, 1981 & 7 \\
\hline$M x-82$ & $\mathrm{C}$ & Wheat & Mexico, 1982 & 7 \\
\hline Mx-85 & $\mathrm{C}$ & Wheat & Mexico, 1985 & 7 \\
\hline Ciano 1982 & $\mathrm{C}$ & Wheat & Mexico, 1982 & 8 \\
\hline Calexico & $\mathrm{T}$ & Wheat & Mexico, $1983^{c}$ & 9 \\
\hline Mexicali CF & $\mathrm{C}$ & Wheat & Mexicali, CA, $1990^{c}$ & 9 \\
\hline Navajoa 1989 MX & $\mathrm{C}$ & Wheat & Mexico, 1989 & 7 \\
\hline Yv3b & $\mathrm{T}$ & Wheat & Mexico, 1989 & 7 \\
\hline Yv3c & $\mathrm{T}$ & Wheat & Mexico, 1989 & 7 \\
\hline Mv-1a & $\mathrm{T}$ & Wheat & Mexico, 1989 & 7 \\
\hline Mv-1c & $\mathrm{T}$ & Wheat & Mexico, 1989 & 7 \\
\hline Fv-1c & $\mathrm{T}$ & Wheat & Mexico, 1989 & 7 \\
\hline Brazil T5 & $\mathrm{T}$ & Wheat & Brazil, intercept, 1991d & 10 \\
\hline \multicolumn{5}{|l|}{ T. barclayana } \\
\hline PJ-11 & $\mathrm{B}$ & Rice & China, 1991 & 11 \\
\hline L201 & B & Rice & California, 1985 & 12 \\
\hline AK-T2 & $\mathrm{C}$ & Rice & Arkansas, 1986 & 4 \\
\hline P-5 & $\mathrm{B}$ & Rice & Philippines, 1989 & 13 \\
\hline $137 \mathrm{aI}$ & B & Rice & Brazil, 1991 & 14 \\
\hline Tsp14 & B & Rice & California, 1982 & 2 \\
\hline Tsp5 & B & Paspalum distichum & Washington, 1982 & 2 \\
\hline \multicolumn{5}{|l|}{ T. tritici } \\
\hline C-100 & $\mathrm{C}$ & Wheat & Washington, 1990 & 15 \\
\hline C-125 & $\mathrm{C}$ & Wheat & Idaho, 1990 & 15 \\
\hline \multicolumn{5}{|l|}{ T. laevis } \\
\hline F-008 & $\mathrm{C}$ & Wheat & Oklahoma, 1989 & 16 \\
\hline \multicolumn{5}{|l|}{$T$. controversa } \\
\hline DB-107 & $\mathrm{C}$ & Wheat & Idaho, 1989 & 15 \\
\hline DB-046 & $\mathrm{C}$ & Wheat & Czechoslovakia, 1989 & 18 \\
\hline DB-131 & $\mathrm{C}$ & Wheat & Montana, 1989 & 15 \\
\hline \multicolumn{5}{|c|}{ T. fusca var. bromitectorum } \\
\hline G-105 & $\mathrm{C}$ & Bromus tectorum & Utah, 1990 & 19 \\
\hline \multicolumn{5}{|l|}{ T. fusca var. guyotiana } \\
\hline G-110 & $\mathrm{C}$ & Bromus brizaeformis & Idaho, 1990 & 19 \\
\hline G-112 & $\mathrm{C}$ & Bromus japonicus & Oregon, 1990 & 19 \\
\hline
\end{tabular}

a $\mathrm{SW}=$ isolate derived from seed wash; $\mathrm{C}=$ isolate derived from mycelia grown from a mixture of teliospores; $\mathrm{T}=$ isolate from the isolation of a single teliospore; $\mathrm{B}=$ isolate from a single basidiospore.

b 1, R. Meyer, USDA APHIS PPQ, Beltsville, MD; 2, L. Carris, Washington State University; Pullman, WA; 3, G. Peterson, USDA ARS, Ft. Detrick, MD; 4, M. Royer, USDA APHIS, Beltsville, MD; 5, M. Bonde, USDA ARS, Ft. Detrick, MD; 6, K. Gill, Punjab Agricultural University, Ludhiana, India; 7, R. Kahn, USDA APHIS, Beltsville, MD; 8, G. Fuentes-Davila, CIMMYT, Mexico; 9, T. Boratynski, APHIS PPQ, El Centro, CA; 10, L. Butler, CIMMYT, El Batan, Mexico; 11, P. Jinhov, Dalian, China; 12, T. Matsumoto, California Department of Agriculture, Sacramento, CA; 13, J. M. Bonman, International Rice Research Institute, Manila, Philippines; 14, C. Castro, EMBRAPA, Brasilia, Brazil; 15, B. Goates, USDA ARS, Aberdeen, ID; 16, I. Williams, Oklahoma State University; Stillwater, OK; 17, G. White, Plant Protection and Quarantine, Agriculture Canada, Ottawa, Canada; 18, R. Vyskumny, Piestany, Czechoslovakia; 19, J. Huffman, USDA, retired, Hanalei, HI. c Quarantine interception from Mexico by U.S. Animal and Plant Health Inspection Service (APHIS).

${ }^{\mathrm{d}}$ Quarantine interception by Empresa Brazileira de Pesquisa Agropecaris (EMBRAPA). 
the Bpop samples began to cross the threshold at the 20th cyling step, whereas YRG-001 did not begin to cross the threshold until the 33rd cycling step. In the $T$. walkeri-specific TaqMan assay, YRG-001 crossed the threshold at the 20th cycling step, while Bpop did not cross the threshold until the 33rd cycling step.

In order to evaluate the accuracy of the two TaqMan assays, DNA extracted from the $34 \mathrm{~T}$. indica and $10 \mathrm{~T}$. walkeri isolates was tested and compared to the classical PCR assays. For the $T$. indica TaqMan assays, all $34 \mathrm{~T}$. indica isolates displayed $\triangle \mathrm{RQ}$ values of at least 1.22 , whereas $\Delta \mathrm{RQ}$ values for the $10 \mathrm{~T}$. walkeri isolates were no greater than 0.12 after 34 cycles (Fig. 4A). Conversely, all $T$. walkeri isolates had $\triangle \mathrm{RQ}$ values of at least 2.21, and none of the $T$. indica isolates had $\Delta \mathrm{RQ}$ values of more than 0.57 using the $T$. walkeri-specific primers Tin11/Tin10 (Fig. 4B). In each instance, the TaqMan assays produced the same results as classical PCR assays using either the $T$. indica-specific primers Tin3/Tin10 or the T. walkeri-specific primers Tin11/Tin10.

To determine the sensitivity limits of both the $T$. indica- and $T$. walkeri-specific $5^{\prime}$ fluorogenic assays, dilutions of purified total mycelial DNA from $T$. indica isolate Bpop and T. walkeri isolate YRG001 were examined (Fig. 5). In both assays, $5 \mathrm{pg}$ of total DNA produced detectable levels of fluorescence ( 0.06 and $0.04 \Delta R Q$ values).
In order to verify the range of species specificity of the $T$. indica- and T. walkeri-specific $5^{\prime}$ fluorogenic assays, purified total mycelial DNA of several different Tilletia species were evaluated (Fig. 6). DNA extracted from T. barclayana, T. tritici, $T$. laevis, $T$. controversa, or $T$. fusca isolates did not amplify in either the $T$. indica- or T. walkeri-specific assay.

\section{DISCUSSION}

Methods for the detection and unambiguous identification of $T$. indica are crucial in order to alleviate unnecessary restrictions that prevent the movement of wheat free of Karnal bunt and hinder international trade of U.S. wheat. Such procedures also serve to clarify issues of pathogen (fungal) taxonomy that may cause confusion in the regulatory processes. Contamination of wheat with teliospores of the ryegrass smut pathogen, $T$. walkeri, is a case in point, raising the need for new diagnostic tests that can discriminate between these two closely related pathogens. Concerns exist that U.S. wheat shipments could be rejected at international ports due to the misidentification of $T$. walkeri teliospores as $T$. indica. Even though T. walkeri has been classified as a new Tilletia species based upon teliospore morphology and ornamentation (7), identification based solely upon a visual assessment of teliospore

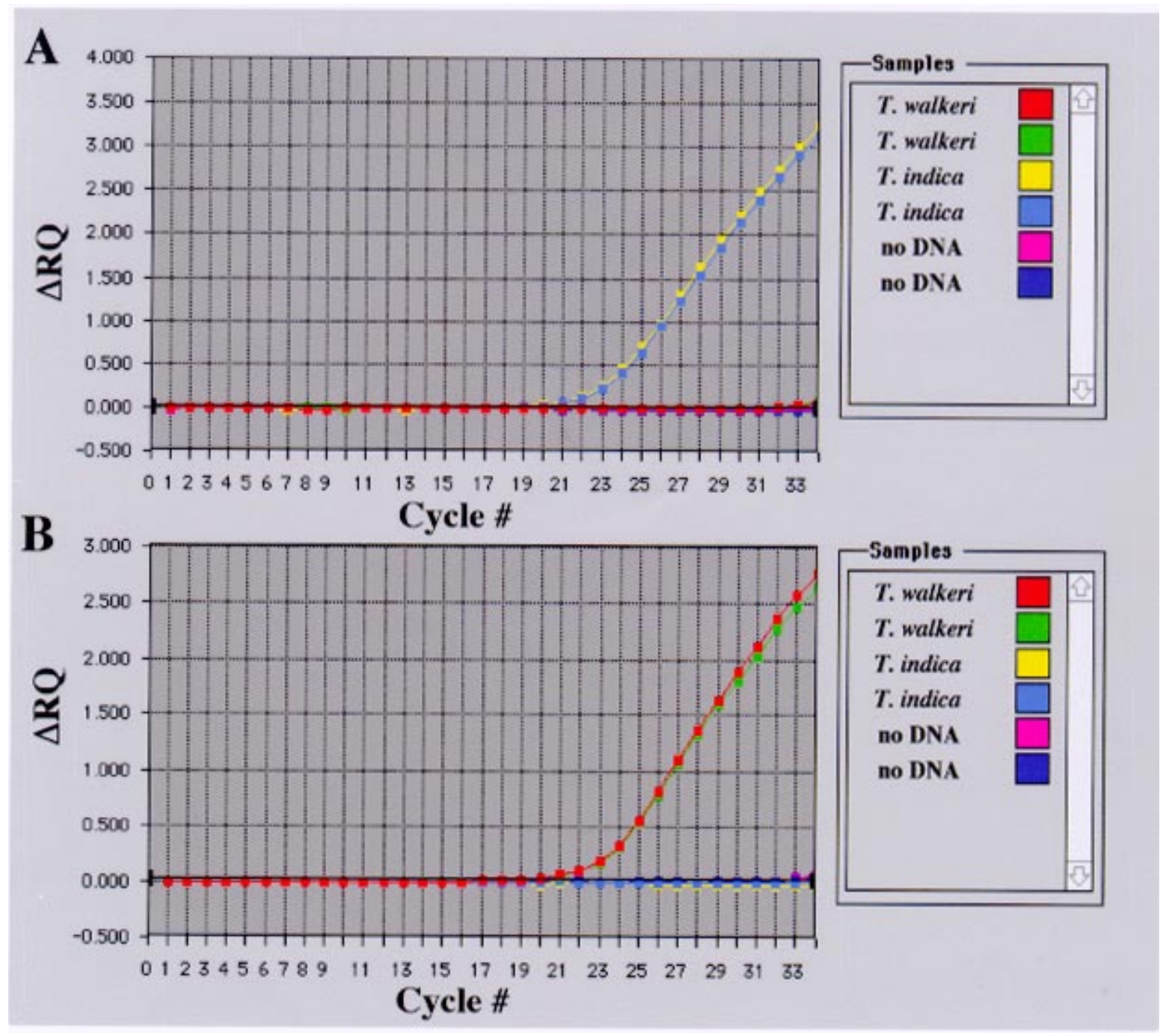

Fig. 3. Amplification of mitochondrial DNA of Tilletia indica isolate Bpop and $T$. walkeri isolate YRG-001 by TaqMan PCR using an ABI Prism 7700 Sequence Detection System (Perkin-Elmer/Applied biosystems, Inc., Foster City, CA). T. indica-specific flanking primers Tin3/Tin10 (A) or T. walkerispecific flanking primers Tin11/Tin10 (B) were used with a $5^{\prime}$-FAM-labeled internal probe sequence. The left axis $(\Delta \mathrm{RQ})$ is the change in fluorescence that is a measure of probe cleavage efficiency, and the bottom axis is the PCR cycling stage. Two independent assays were analyzed using duplicate DNA samples for each isolate. 
morphology is not acceptable. Therefore, we pursued the development of a molecular diagnostic test for the detection, identification and discrimination of the two Tilletia species: $T$. indica and T. walkeri.
Detection assays using classical PCR techniques have been developed for numerous plant pathogens, including bacteria, viruses, and fungi (14). These tests are attractive for several reasons. First, the assays are extremely sensitive and highly specific for the

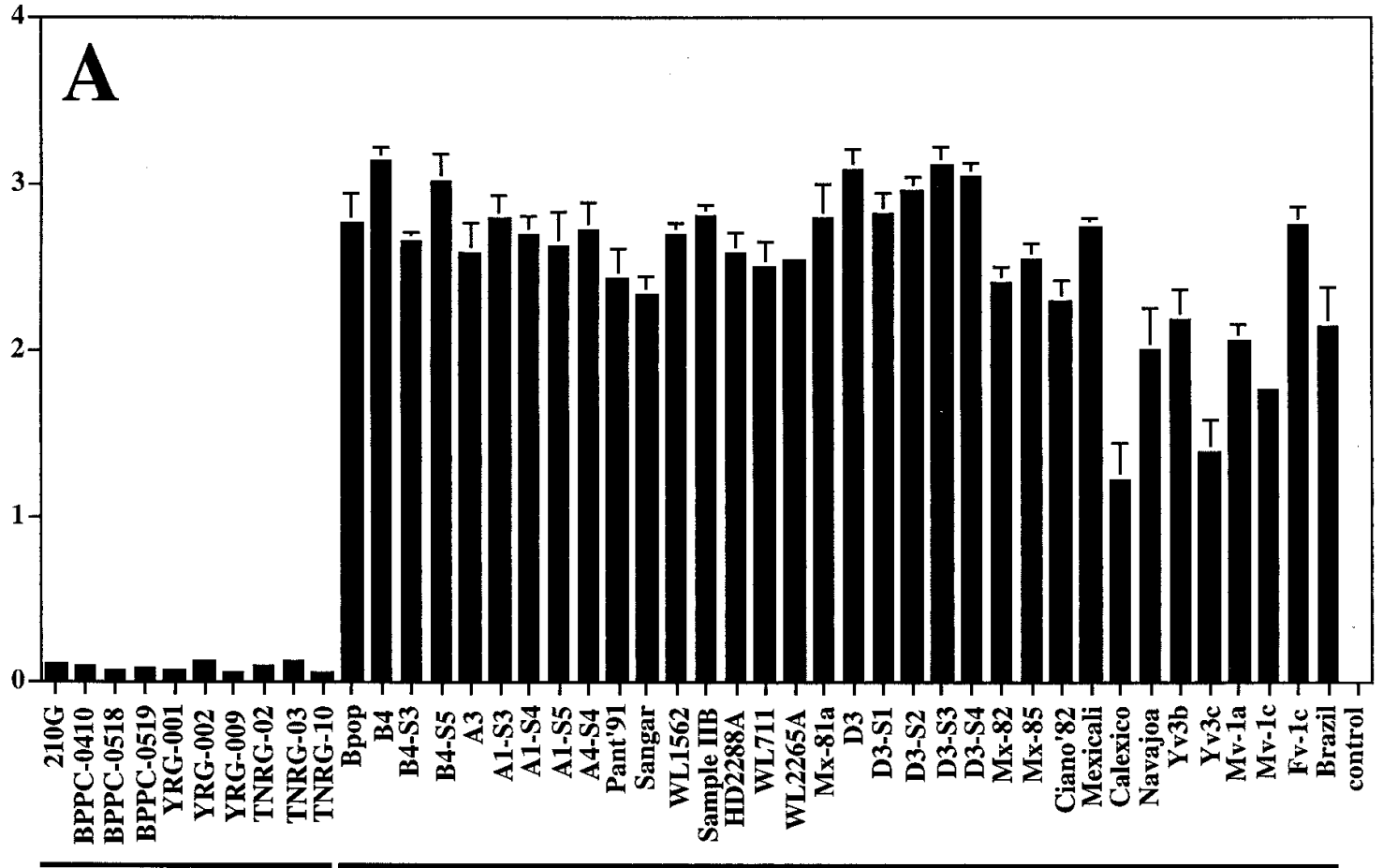

T. walkeri

T. indica

Isolates

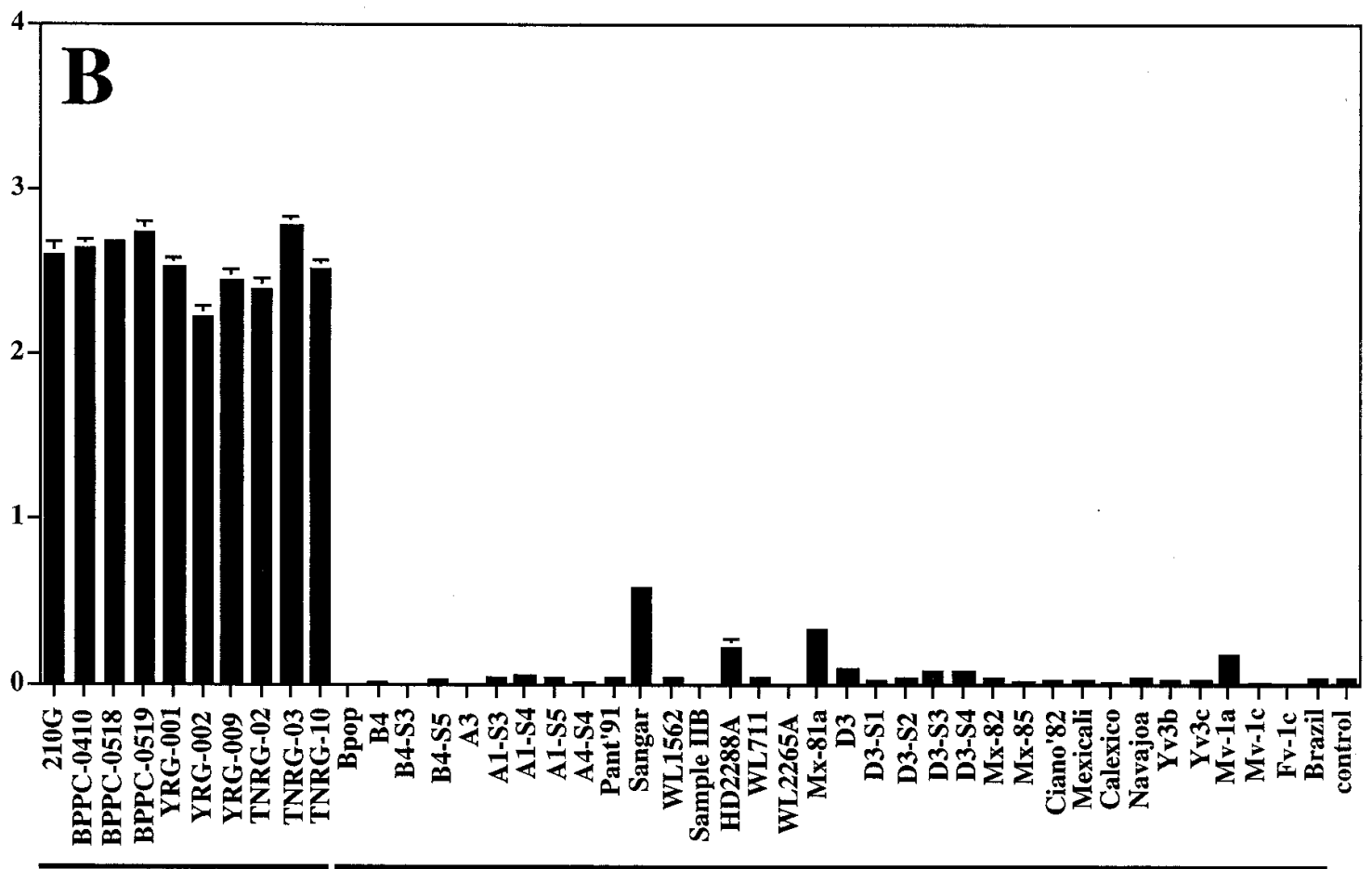

T. walkeri

T. indica

Isolates

Fig. 4. TaqMan polymerase chain reaction amplification of mitochondrial DNA of Tilletia indica isolates and T. walkeri isolates using either the T. indicaspecific flanking primers Tin3/Tin10 (A) or the T. walkeri-specific flanking primers Tin11/Tin10 (B) after 34 amplification cycles. The $\Delta \mathrm{RQ}$ values are the means of two independent experiments with duplicate DNA samples. Error bars represent standard errors of the means. 
pathogen in question. Second, PCR tests require minimal amounts of sample material, and commercial kits are available for extracting high quality genomic DNA from a wide variety of organisms. Finally, PCR reactions are relatively simple to set up and perform, and results can be obtained quickly, usually in a day.

Little is known about the genome or gene structure in Tilletia spp., including $T$. indica. Differences in chromosome number and size have been found among $T$. indica isolates (24), and genetic variation has been observed among isolates of $T$. indica, $T$. barclayana, and T. walkeri, either from PCR-RFLP analysis of
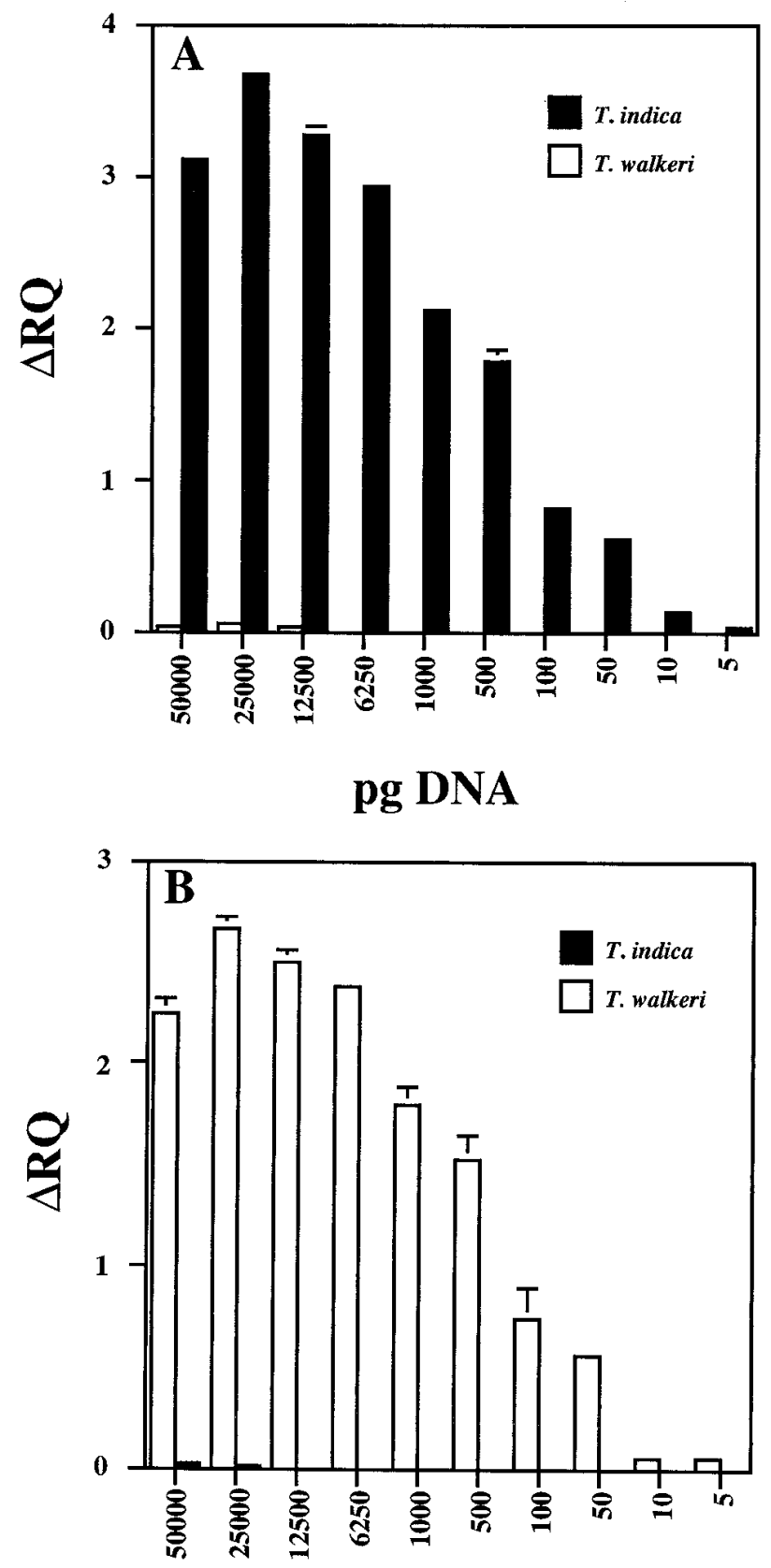

pg DNA

Fig. 5. Detection limits of Tilletia indica and T. walkeri DNA by the TaqMan polymerase chain reactions assays using either the $T$. indica-specific flanking primers Tin3/Tin10 (A) or the $T$. walkeri-specific flanking primers Tin11/Tin10 (B) after 34 amplification cycles. The $\Delta R Q$ values are the means of two independent experiments that had duplicate DNA samples. Error bars represent standard errors of the means. Dilution series of template DNA were prepared from $T$. indica isolate Bpop and $T$. walkeri isolate YRG-001. the rDNA or from RAPD analysis (19). Any new PCR assay procedure to distinguish between $T$. indica and $T$. walkeri requires specific PCR primers to unique DNA sequences in each of the two species. Therefore, nucleotide sequence information from both $T$. indica and T. walkeri is a prerequisite for any PCR assay.

Previously, a 2.3-kb fragment was amplified by PCR using the primers Ti-1 and Ti-4 that was characteristic for $T$. indica isolates. DNA extracted from other smut fungi, including $T$. barclayana, $T$. caries, T. controversa, T. laevis, T. fusca var. fusca, and T. fusca var. bromitectorum, did not produce DNA bands using these two

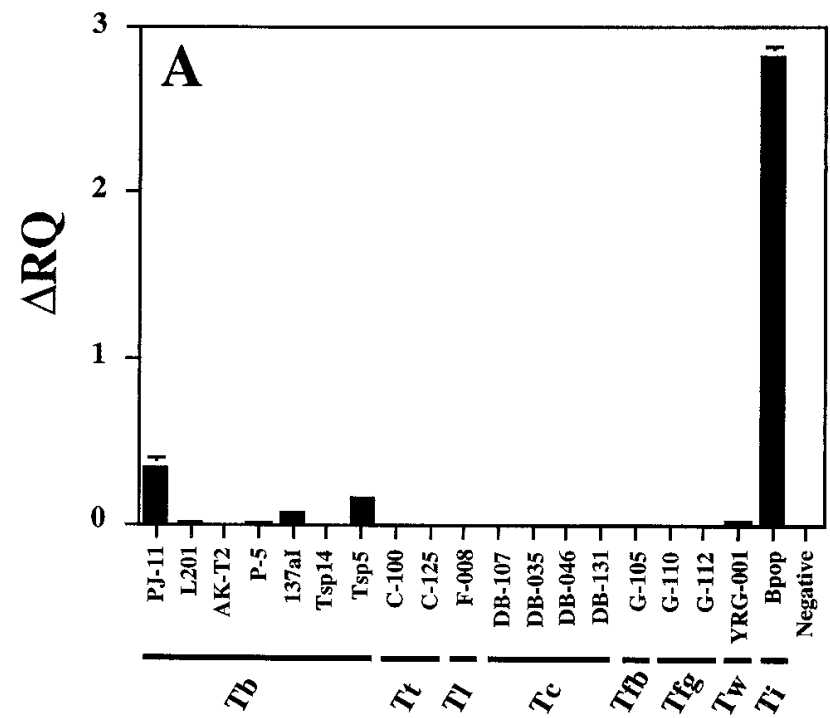

Isolate

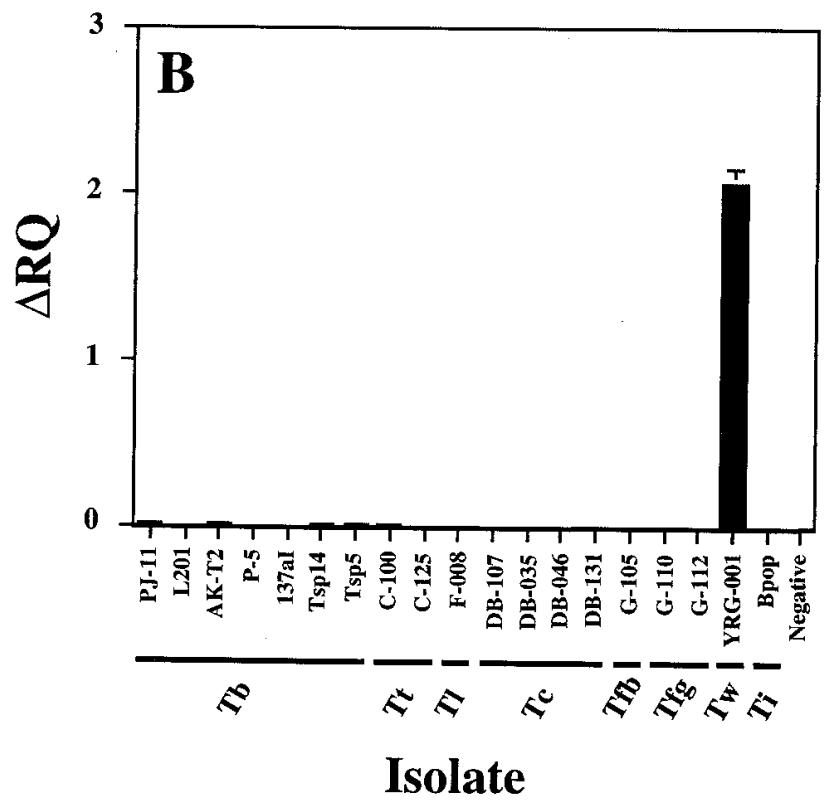

Fig. 6. TaqMan polymerase chain reaction amplification of mitochondrial DNA of Tilletia species using either the $T$. indica-specific flanking primers Tin3/Tin10 (A) or the T. walkeri-specific flanking primers Tin11/Tin10 (B) after 34 amplification cycles. Duplicate DNA samples were analyzed for each isolate. T. barclayana (Tb): PJ-11, L201, AK-T2, P-5, 137aI, Tsp14, and $\mathrm{Tsp} 5 ; T$. tritici $(\mathrm{Tt}): \mathrm{C}-100$, and $\mathrm{C}-125 ;$ T laevis (Tl): $\mathrm{F}-008 ; T$. controversa (Tc): DB-107, DB-035, DB046, and DB131; T. fusca var. bromitectorumi (Tfb): G-105; T. fusca var. guyotiana (Tfg): G-110, and G-112; T. walkeri (Tw): YRG-001; and T. indica (Ti): Bpop. 
PCR primers (11). However, subsequent to the discovery of $T$. walkeri, a similar-sized $2.3-\mathrm{kb}$ fragment was found to amplify from all available $T$. walkeri isolates using the PCR primers Ti-1 and Ti-4. We decided to clone the 2.3-kb fragment amplified by PCR using the primers Ti- 1 and Ti-4 from several T. walkeri and $T$. indica isolates and compare the nucleotide sequences between these two Tilletia species.

Consistent nucleotide differences were found between $T$. indica and T. walkeri isolates that allowed for species-specific PCR primers to be designed. Five sets of PCR primers were made and shown to be highly specific only for $T$. indica isolates and not for any other Tilletia species, including $T$. walkeri. In addition, three PCR primer sets were developed that amplified single DNA bands only from $T$. walkeri isolates and not from any of the T. indica Isolates tested. In the future, smut teliospores isolated from wheat can be definitively identified either as $T$. indica or $T$. walkeri by using these species-specific PCR primers.

In addition to developing classical PCR assays, we adapted a set of $T$. indica- and $T$. walkeri-specific PCR primers for use with an internal $5^{\prime}$-FAM-labeled oligonucleotide probe sequence in a 5'-fluorogenic TaqMan PCR assay. In most 5'-fluorogenic TaqMan PCR assays, the flanking PCR primers are the same, and the internal fluorescent-labeled probe is designed to be characteristic for a specific sequence $(3,15)$. Since the nucleotide differences within the $2.3-\mathrm{kb} \mathrm{mtDNA}$ region of $T$. indica and $T$. walkeri were randomly scattered, we chose instead to use the same probe sequence and to use different flanking primers specific either to $T$. indica or T. walkeri. Primer Tin3 provides specificity for T. indica isolates, while Tin11 is used for T. walkeri isolates. In both PCR assays, Tin10 is used with either Tin 3 or Tin11, and the size of both amplicons is $212 \mathrm{bp}$.

The TaqMan detection assays offer several advantages over the classical PCR assays developed for T. indica or T. walkeri. The TaqMan assays combine the sensitivity of PCR along with hybridization of the internal oligonucleotide sequence that is present in a $T$. indica or $T$. walkeri mtDNA sequence. Following PCR, samples do not have to be separated on agarose gels, and the subsequent Southern blots and hybridization steps necessary to verify the identity of the PCR products are eliminated. Such additional post-PCR confirmation steps can add several days to the process of accurate pathogen identification. Using the TaqMan system, the $T$. indica- or $T$. walkeri-specific $5^{\prime}$-fluorogenic assays are completed within $2.5 \mathrm{~h}$, and 96 samples can be tested during a single assay. As a result, large numbers of test samples can be accurately identified in a very short period of time with the TaqMan assay, and time can be critical when wheat shipments are being held at port due to the presence of smut teliospores.

Another advantage of the TaqMan system is the potential for multiplexing. 5'-fluorogenic assays have been used to detect other pathogenic microorganisms, including plant pathogenic bacteria (20) and viruses (21), and human fungal pathogens $(6,22)$. Different fluorescent reporter dyes can be used to construct probes, and several different pathogen systems can be combined in the same PCR reaction. This reduces the labor costs that would be incurred if each of the tests were performed separately.

This is the first application of the TaqMan system for the detection and identification of plant pathogenic fungi. This assay will be extremely useful to resolve disputes regarding contamination of wheat with smut teliospores.

\section{ACKNOWLEDGMENTS}

We would like to thank A. Tschanz, L. Levy, and M. Palm from USDA-APHIS and L. Castlebury, USDA-ARS for useful discussions and sharing data at joint USDA-ARS/USDA-APHIS Karnal bunt meetings. In addition, we gratefully acknowledge the financial support of USDAAPHIS that funded portions of this research initiative. We thank E. Hatziloukas for suggesting the T. indica primer sequences F3 and R1, and R. Jones, V. Damsteegt, W. Bruckart, and D. Luster for critically reviewing the manuscript.

\section{LITERATURE CITED}

1. Altschul, S. F., Madden, T. L., Schaffer, A. A., Zhang, J., Zhang, Z., Miller, W., and Lipman, D. J. 1997. Gapped BLAST and PSI-BLAST: a new generation of protein database search programs. Nucleic Acids Res. 25:33893402 .

2. Ausubel, F. M., Brent, R., Kingston, R. E., Morre, D. D., Seidman, J. G., Smith, J. A., and Struhl, K. (eds.). 1987. Current Protocols in Molecular Biology. John Wiley \& Sons. New York.

3. Bassler, H. A., Flood, S. J. A., Livak, K. J., Marmaro, J., Knorr, D. A., and Batt, C. A. 1995. Use of a fluorogenic probe in a PCR-based assay for the detection of Listeria monocytogenes. Appl. Environ. Microbiol. 61:3721-3728.

4. Bonde, M. R., Peterson, G. L., Fuentes-Davila, G., Aujila, S. S., Nanda, G. S., and Philips, J. G. 1996. Comparison of the virulence of isolates of Tilletia indica, causal agent of Karnal bunt of wheat, from India, Pakistan, and Mexico. Plant Dis. 80:1071-1074.

5. Bonde, M. R., Peterson, G. L., Schaad, N. W., and Smilanick, J. L. 1997. Karnal bunt of wheat. Plant Dis. 81:1370-1377.

6. Brandt, M. E., Padhye, A. A., Mayer, L. W., and Holloway, B. P. 1998. Utility of random amplified polymorphic DNA PCR and TaqMan automated detection in molecular identification of Aspegillus fumigatus. J. Clin. Microbiol. 36:2057-2062.

7. Castlebury, L. A., and Carris, L. M. 1999. Tilletia walkeri, a new species on Lolium multiflorun and L. perenne. Mycologia 91:121-131.

8. Cunfer, B. M., and Castlebury, L. A. 1999. Tilletia walkeri on annual ryegrass in wheat fields in the southeastern United States. Plant Dis. 83:685-689.

9. Deverex, J., Haeberli, P., and Smithies, O. 1984. A comprehensive set of sequence analysis programs for the VAX. Nucleic Acids Res. 12:387395.

10. Duran, R. 1972. Further aspects of teliospore germination in North American smut fungi. Can. J. of Bot. 50:2569-2573.

11. Ferreira, M. A. S. V., Tooley, P. W., Hatziloukas, E., Castro, C., and Schaad, N. W. 1996. Isolation of species-specific mitochondrial DNA sequences for identification of Tilletia indica, the Karnal bunt of wheat fungus. Appl. Environ. Microbiol. 62:87-93.

12. Frederick, R. D., Snyder, K. E., Tooley, P. W., Berthier-Schaad, Y., Peterson, G. L., Bonde, M. R., Schaad, N. W., and Knorr, D. A. 1998. An improved PCR method utilizing TaqMan for the detection and differentiation of Tilletia indica, the causal organism of Karnal bunt of wheat, and a related ryegrass smut. Phytopathology 88:S29.

13. Frederick, R. D., Tooley, P. W., Berthier-Schaad, Y., Peterson, G. L., Bonde, M. R., and Schaad, N. W. 1998. Differentiation between Tilletia indica, the causal organism of Karnal bunt of wheat, and a related ryegrass smut using PCR. (Abstr.) Proc. 7th Intl. Congress of Plant Pathology, Edinburgh, Scotland.

14. Henson, J. M., and French, R. 1993. The polymerase chain reaction and plant disease diagnosis. Annu. Rev. Phytopathol. 31:81-109.

15. Livak, K. J., Flood, S. J. A., Marmaro, J., Giusti, W., and Deetz, K. 1995. Oligonucleotides with fluorescent dyes at opposite ends provide a quenched probe system useful for detecting PCR product and nucleic acid hybridization. PCR Methods Appl. 4:357-362.

16. Mitra, M. 1931. A new bunt of wheat in India. Ann. Appl. Biol. 18:178179.

17. Mullis, K. B., and Faloona, F. A. 1989. Specific synthesis of DNA in vitro via a polymerase-catalyzed chain reaction. Meth. Enzymol. 155:335-350.

18. Palm, M. E. 1999. Mycology and world trade: A view from the front line. Mycologia 91:1-12.

19. Pimentel, G., Carris, L. M., Levy, L., and Meyer, R. J. 1998. Genetic variability among isolates of Tillietia barclayana, T. indica, and allied species. Mycologia 90:1017-1027.

20. Schaad, N. W., Berthier-Schaad, Y., Sechler, A., and Knorr, D. 1999. Detection of Clavibacter michiganensis subsp. sepedonicus in potato tubers by BIO-PCR and an automated real-time fluorescence detection system. Plant Dis. 83:1095-1100.

21. Schoen, C. D., Knorr, D., and Leone, G. 1996. Detection of potato leafroll virus in dormant potato tubers by immunocapture and a fluorogenic 5' nuclease RT-PCR assay. Phytopathology 86:993-999.

22. Shin, J. H., Nolte, F. S., Holloway, B. P., and Morrison, C. J. 1999. Rapid identification of up to three Candida species in a single reaction tube by a 5' exonuclease assay using fluorescent DNA probes. J. Clin. Microbiol. $37: 165-170$

23. Smith, O. P., Peterson, G. L., Beck, R. J., Schaad, N. W., and Bonde, M. R. 1996. Development of a PCR-based method for identification of 
Tilletia indica, causal agent of Karnal bunt of wheat. Phytopathology 86:115-122.

24. Tooley, P. W., Carras, M. M., Beck, R., Peterson, G., and Bonde, M. R. 1995. Separation of Tilletia indica chromosomes using CHEF gel electrophoresis. Mycologia 81:61-67.

25. White, T. J., Bruns, T., Lee, S., and Taylor, J. 1990. Amplification and direct sequencing of fungal ribosomal RNA genes for phylogenetics. Pages 315-322 in: PCR Protocols. M. A. Innis, D. H. Gelfand, J. J. Sninski and T. J. White, eds.,. Academic Press, Inc. San Diego.

26. Ykema, R. E., Floyd, J. P., Palm, M. E., and Peterson, G. L. 1996. First report of Karnal bunt of wheat in the United States. Plant Dis. 80:1207. 